\title{
3 A dynamic multi-field approach
}

\author{
Elin Lerum Boasson
}

\section{Introduction}

The multi-field approach is developed to facilitate study of organizational and political factors that shape the development of public policy. Many fields play into developments of domestic support-scheme support. Each field has an identifiable social architecture: a distinct distribution of structural resources and certain specific cultural-institutional characteristics (Boasson 2015: 1). The multi-field approach is a spatial, relational approach to understanding how actors interact with one another (Kluttz and Fligstein 2016: 186). This unit of analysis - a given field - is 'neither a macro-social process that contains some underlying structural logic operating independently of actors (e.g., social class) nor is it a micro-social process that focuses on the idiosyncratic preferences and motivations of individual actors' (Kluttz and Fligstein 2016: 186). A field is a socially distinct constellation of actors, with varying degrees of internal coherence, unity and autonomy, and more or less impenetrable boundaries. Thus, a field is not an actor as such, but a distinct social space with some coherence across actors.

In this chapter, we conceptualize three specific fields - the European environment, the domestic organizational field and the domestic political field - and their interrelationships. All three can be seen as social arenas where the actors take one another into account; and all have a local social order that constrains, facilitates or enables certain behaviours and policy developments (Kluttz and Fligstein 2016: 186; Scott [2001] 2014). In this chapter, we develop specific expectations that are examined in the six case studies presented in Part II of this volume. In turn, these expectations form the basis for the systematic comparisons in Part III.

\section{The European environment}

We see the European environment as a meta-field, embracing EU-specific developments as well as what goes on in EU member states. It comprises all the domestic political fields and organizational fields in states that are members of, or otherwise affiliated to, the European Union, as well as the European Commission (the Commission), EU-level agencies, the European Parliament, the Court of Justice of the European Union (CJEU) and non-governmental organizations dealing 
with specific issue-areas. All EU-affiliated countries are likely to be affected by the European environment, although not in the same way or to the same extent.

\section{Vertical Europeanization}

In principle, two European renewables policy processes may play out at the same time: vertical and horizontal Europeanization. We understand vertical Europeanization as top-down EU steering, resulting from the EU having formal authority within an issue-area (Bulmer and Radaelli 2004: 5). Vertical integration will be strong when the EU rules in question are detailed and specific; when the Commission can develop detailed guidelines or templates, monitor and facilitate implementation; when the Commission and the CJEU have juridical, coercive follow-up mechanisms available and when EU agencies and the Commission gather and distribute significant information (Boasson 2015: 53-58). Early studies of compliance with EU regulations focused on their coerciveness (Mastenbroek 2005). For instance, in 2001, Thomas Risse and colleagues saw Europeanization primarily as 'the emergence and development at the European level of distinct structures of governance' (Risse et al. 2001: 3).

The capacity of the EU system to influence policy development at the national level depends mainly on the extent to which the EU has formal authority and on the ability of the EU organization to gather and distribute information. The emergence of new European authority structures does not necessarily mean that domestic governance loses importance: such authority structures often supplement national authority structures rather than replace them (Newman 2008: 121). Not only will more policy solutions be developed at the European level, but national implementation of EU policy is more likely to engage other participants than in the case of regular processes of national policy development (Schattschneider 1960: 17-18). Only empirical investigation can show which national actors lose influence and which ones may benefit from this change (Jörgens and Solorio 2017: 11-16).

Like many other policy issues, renewables support schemes concern more than one stream of EU steering. Since the 1990s, the EU has had a specific renewables energy policy, as well as rules on state aid that have also applied to renewables support schemes (Boasson 2021, this book). A key element of EU renewables policy is the directives on renewables that have been repeatedly revised through ordinary EU legislative procedures (formerly called co-decision). Regarding state aid, shifts in the authority of the EU may result from changes in the state-aid rules in the Treaty on the Functioning of the EU (TFEU) (although this has not occurred in the period studied here), changes in the rulings of the CJEU and/or shifts in relevant state-aid guidelines adopted by the Commission. Such guidelines must draw on the Treaty and CJEU case law; whereas they are not legally binding on member states, they are binding on the Commission (Boasson 2021, this book).

As regards information, inter-governmentalists tend to argue that the Commission has few resources for gathering and distributing information (e.g. Moravcsik 1999), but others disagree. Multi-level governance perspectives on EU studies 
underline how the Commission, and to some extent the European Parliament, can enhance their structural power by creating and governing pan-European expert and policy networks (Eising 2004: 218; Hooghe 2001; Hooghe and Marks 2001; Kohler-Koch 1999; Mazey and Richardson 2006). Scholars of public administration hold that the Commission and the EU agencies have developed significant capacities that work rather independently of domestic administrations (Trondal 2017). In this sense, the Commission may develop superior access to information, as well as a potentially superior ability to distribute information.

Vertical Europeanization captures the 'domestic impact of Europe and the EU' in the sense that domestic actors adapt and change domestic policies and institutions in response to EU rules and regulations (Börzel and Risse 2012: 6). This mode of Europeanization will probably have more far-reaching consequences when backed by strict coercive measures, but it may also be influential when EUlevel impulses are of a softer character. For instance, member states may respond to the Commission's preparation of new decisions, or political discussions at the EU level, and not only to outputs from formal EU-level ruling and decisionmaking. After all, a broad array of EU and member-state actors repeatedly and continuously engage in discursive, deliberative processes, where new and old ideas are discussed, developed and either promoted or dismissed (Schmidt 2018).

EU actors, such as the Commission and the CJEU, may under certain conditions influence domestic developments more than their formal, juridical powers might lead us to expect. After all, countries may do more than they are strictly obliged to - what Eva Thomann (2015) has called 'customizing', as when countries adopt policies in a way that leads to more and/or stricter rules and practices than required (Thomann 2015: 1370). For instance, member states may adopt more encompassing renewables support mixes than EU law obliges them to do, or interpret EU state-aid guidelines in a more restrictive way than strictly required. Still, we expect vertical Europeanization to shape domestic support-scheme mix developments more when the EU has gained superior structural powers (authority and information) within the issue-area in question.

Because the countries examined here have differed in their relationships to the EU during the period under study, we do not expect them to be influenced to the same extent and in the same way by vertical Europeanization. For instance, a country that joined the EU late (like Poland) and one that is not a full member of the EU (Norway) will probably be less influenced by vertical Europeanization.

\section{Horizontal Europeanization}

Europeanization may also influence national developments through means other than top-down EU steering. Horizontal Europeanization refers to how ideas, measures or policy designs may diffuse across countries and fields within the European environment through socialization, contestation, deliberation, learning and the construction of broader systems of meanings and collective understandings (Boasson 2015; Börzel and Risse 2012; Cowles and Risse 2001: 219; Jörgens and Solorio 2017: 12-13). This mode of Europeanization plays out irrespective of 
EU-level developments and entails a broad array of horizontal linkages and interactions. In 2001, Maria Green Cowles and Thomas Risse (2001:219) pointed out how Europeanization consists of constructing systems of meanings and collective understandings, not merely systems of authority. Claudio Radaelli (2003: 30) has conceptualized EU policy development as an institutional process, centred on emergence and diffusion of 'ways of doing things' as well as shared beliefs and norms.

Horizontal Europeanization centres on the processes whereby actors redefine their beliefs and preferences as a result of what other actors are doing, and the socialization process they are part of (Dobbin et al. 2007: 452; March and Olsen 1989). Horizontal Europeanization has been variously labelled 'policy diffusion', 'horizontal policy learning', 'policy convergence' or 'policy transfer' (Börzel and Risse 2012; Jörgens and Solorio 2017: 12-16). Policy recipes begin to diffuse because countries mimic each other, learn from each other or compete with each other; the existence of European-wide networks or expert groups may enhance these effects (Dobbin et al. 2007: 452). For instance, a country may aim to develop a renewables support mix that is rather similar to what others have - although it is adjusted to special domestic circumstances (Dobbin et al. 2007: 457-459). The cumulative effect of many countries adopting the same policy recipe will create 'peer pressure' among countries (Finnemore and Sikkink 1998: 903).

According to the neo-institutional literature, when a policy recipe diffuses, it gains legitimacy, and the pressure on individual actors to adjust to the new policy idea will increase (see Finnemore and Sikkink 1998; Meyer 2000; Meyer et al. 1997; Meyer and Rowan 1977). The more countries that have adopted a certain model, the stronger will be the pressure for others to adopt it (Meyer and Rowan 1977). The actions of large and dominant countries within an issue-area may be particularly important. Hence, the more a specific policy recipe dominates within the European environment, the more likely is it to affect domestic-level developments in any given country. This may take place when the idea for designing a given support scheme is adopted by many countries at the same time and/ or the idea is discussed and promoted within organizational and political fields across the entire European environment. We expect horizontal Europeanization to dominate domestic support-scheme mix developments more when one particular support-scheme idea gains popularity across the European environment.

\section{Expectations}

Horizontal and vertical Europeanization may operate rather independently of each other - indeed, under certain conditions, they may even counteract each other whereas at other times they may have a reinforcing effect. For instance, increased horizontal coherence may underpin the emergence of strong EU steering - or stronger EU steering may spark horizontal coherence.

Table 3.1 shows how the two dimensions of Europeanization may relate to each other, and how they in conjunction can have a bearing on how the European environment will influence domestic support-scheme developments. EU governing 
Table 3.1 Four modes of Europeanization

\begin{tabular}{lll}
\hline $\begin{array}{c}\text { Vertical Europeanization } \\
\text { Horizontal Europeanization }\end{array}$ & The EU is superior & Distributed responsibility \\
\hline Coherence & $\begin{array}{l}\text { EU GOVERNING } \\
\text { Drives domestic policy } \\
\text { developments }\end{array}$ & $\begin{array}{l}\text { HORIZONTAL } \\
\text { HARMONIZATION }\end{array}$ \\
UNPREDICTABLE EU & $\begin{array}{l}\mathbf{1 0 0 0} \text { FLOWERS } \\
\text { Domestic developments } \\
\text { GOVERNING }\end{array}$ & $\begin{array}{l}\text { largely disconnected from } \\
\text { European developments }\end{array}$ \\
\hline
\end{tabular}

Source: Revised version of Boasson (2015: 55).

and 1000 flowers are contrasting modes. With EU governing, the EU has the upper hand in the policy area, and one policy model dominates: the EU is vertically superior, and there is horizontal coherence across the EU/EEA. In such situations, national actors will likely have few ideas for the design of an alternative renewables support scheme - but if they want to adopt different schemes, they will not have much opportunity to bend the steering signals coming from the EU. However, as EU steering relies on member-state support, this is not a completely top-down situation. Also in issue-areas where the Commission enjoys considerable leeway, such as state aid, the Commission will be partly constrained by the member states. There will be continuous and close dialogue between EU-level fields and domestic fields in EU governing situations, but in the end, the EU-level decisions will count more for domestic developments. Changes as well as continuities in domestic support schemes will be closely related to developments at the EU level.

The 1000 flowers (from the dictum made famous by Mao Zedong, 'let a thousand flowers bloom') will operate when vertical Europeanization (formal responsibility distributed among member states) and horizontal Europeanization are weak (wide diversity in national approaches). This will be the situation for new policy areas not yet covered by EU policy, but it may also occur where the EU has failed to agree on any specific policies and member states apply a panoply of different policy measures. In such cases, domestic policy developments will interact with the larger European environment only if instigated by national-level actors: it is the national conditions that determine whether the domestic support-scheme mix will be influenced by the European environment.

Horizontal harmonization will occur when strong horizontal Europeanization promotes a given renewables support-scheme design, but the EU has not been granted much formal authority to promote this design: the harmonization will result from countries influencing, mimicking, learning or competing with each other. Waves of similar support schemes may be created, but primarily because the domestic fields are open to European impulses. Also, there may be significant variation in how a particular support scheme idea is interpreted nationally. The 
cross-country interaction between domestic fields increase, but with less interaction between the EU fields and domestic fields.

Lastly, unpredictable EU governing may emerge in cases where the EU has been granted considerable authority but many policy models are in use. Conflicts over how to interpret the EU rules will be rampant, and the room for negotiation between national governments and the EU considerable. Potentially the EU has considerable power, but its actual influence on national policy outcomes will hinge largely on the strategic capabilities of national actors and their bargaining skills.

The role and importance of the European environment will always depend on how it relates to and interacts with the domestic fields, but we expect the European environment to:

- dominate the development of national renewable energy policies more when vertical Europeanization is strong and horizontal Europeanization is coherent, so that one specific support-scheme mix gains superiority (EU governing).

\section{Domestic organizational fields}

John W. Kingdon ([1984] 2011) has argued that various policy issues will be embedded in different 'policy communities'. In line with this, we hold that policies will be embedded in domestic organizational fields made up of specialists in a given policy area. An organizational field consists of governmental bodies, regulators, industry, business organizations and non-governmental organizations (NGOs) relating to a certain policy, such as renewables support mixes. Organizational fields are issue- or industry-specific configurations of governmental and private organizations, characterized by identifiable structural interrelationships and certain common institutional understandings. To understand how organization fields influence policy development, we need to explore their social architecture and how this changes over time and varies across fields.

Varying organizational fields will have varying structural and institutional characteristics. Initially, sociological institutionalists tended to define organizational fields as fairly unified, but it is now widely recognized that there will be major variation across fields (Wooten and Hoffman 2017). Further, as pointed out by Baumgartner and Jones ([1993] 2009: 6), historical factors will render some policy areas open to change at certain times but not others. Kingdon notes that some communities 'are extremely closed and tightly knit', while others are more 'diverse and fragmented' (Kingdon [1984] 2011: 118). In the 1980s, several network scholars developed typologies aimed at capturing such variation (for a review, see Börzel 1998). For instance, Rhodes and Marsh placed their network types on a continuum ranging from highly integrated policy communities on the one end to loosely integrated issue networks at the other (Rhodes and March 1992). More recently, scholars of regulatory capture have explicitly recognized that different kinds of state-business relations will produce variance in policy influence. For instance, Daniel Carpenter and David A. Moss (2014: 11) 
distinguish between strong capture and weak capture, adding that 'to the extent capture exists, it prevails by degrees rather than by its presence and absence'.

All the same, we need deeper and more general insights into how different industry-government nexuses may influence policy developments. Lack of a common terminology has hindered the emergence of a cumulative research tradition.

\section{Structural resources}

The social architecture of organizational fields may vary along structural as well as cultural-institutional dimensions. Firstly, the distribution of structural resources, such as authority and information, will influence the importance of the organizational field for policy-making. The distribution of authority will be shaped by laws and regulations, economic agreements between firms, organizational charts, ownership structures and so forth (Scott et al. 2000: 358-400). Neil Fligstein and Doug McAdam (2012: 14) argue that a field may be hierarchically governed, or characterized by collaboration among fairly equal organizations; the latter opens the way to looser coordination and competition between several groups.

Whether public or private organizations possess more authority and control of information will vary from field to field. Governmental organizations may have the upper hand in more regulated industries, but strong regulatory traditions may also create firm bonds between corporate and public organizations (Carpenter and Moss 2014). Further, in industries dominated by a few corporations, authority may be concentrated among a small group of corporate executives, whereas it will tend to be more evenly distributed in industries with many small organizations (Egeberg 2003: 7; Fligstein and McAdam 2012; Olsen 1983). Actors with superior authority may have significant control of information, but it may also be that other actors control the two sources of structural power (Boasson 2015: 49).

Concerning climate and energy technologies and investments, commercial organizations will generally have more information than public actors. A government may remain independent of the information provided by industry only if it possesses substantial organizational capacity and in-house technical-economic expertise. If formal requirements give the government access to detailed commercial information, this can create a more level playing field with respect to information distribution. Against this backdrop, we expect the organizational field to dominate policy development more when structural resources (authority and information) are concentrated.

\section{Institutional logics}

The influence and role of the organizational field will also depend on the degree of cultural-institutional unity. Early organizational field studies portrayed the institutional features of these fields as rather unified. For instance, DiMaggio and Powell ([1983] 1991: 65) argued that the 'development of mutual awareness among participants in a set of organizations that they are involved in a common enterprise' provided an institutional 'glue' that caused all actors in a given 
organizational field to resemble each other, for instance by adopting similar norms and worldviews.

Similarly, Lowi (1964: 689) argued that established expectations and history of earlier decisions create particular understandings and mind-sets. Eventually, certain professional norms will come to define the 'proper' ways of doing things, and rules of the game that serve established interests will become entrenched (Lowi 1969: 92). Hence, a field's origin and the ensuing social processes shape its institutional hallmarks. The more closely knit the community is, the more likely it is to generate common outlooks, orientations and ways of thinking (Kingdon [1984] 2011: 119; Schneiberg and Clemens 2006; Scott et al. 2000; Selznick 1957). Moreover, cultural-institutional unity is likely to contribute to making organizational fields more influential, whereas internal conflict will have the opposite effect: 'if the group is plagued by internal dissension, its effectiveness is seriously impaired' Kingdon ([1984] 2011: 52).

The issue of change, rather than stability, has gained increasing attention in organizational field studies (Wooten and Hoffman 2017). The introduction of the term 'intuitional logic' has played a major role in this analytical transition. An institutional logic provides a basically coherent template for how to act in different situations (Boasson 2015: 50; Thornton 2004; Thornton and Ocasio 1999, 2008). Logics are the basis for action: they shape which issues and problems to attend to, and what answers and solutions are available (Thornton 2004: 13-14). Different logics will embody different senses of rationality and create different expectations as to how persons may behave in various situations (March and Olsen 1989; Thornton et al. 2012: 9).

Shifts in institutional logics may lead to radical changes in the actions of fieldlevel members (see e.g. Greenwood and Suddaby 2006; Thornton 2004; Wooten and Hoffman 2017). This means that if dominance shifts from one logic to another, field-level actors will change their views, perhaps promoting policy measures that they had previously rejected. The existence of multiple institutional logics enables actors to challenge existing orders as well as propose new policy options (Lounsbury 2007: 302; Reay and Hinings 2009). For instance, actors who are dissatisfied with a given policy will be strengthened if they can argue that it contradicts the dominant logic, and if they can propose a new policy measure more in line with the dominant logic.

Thornton (2004) has specified several important institutional logics in modern societies; more recently, Boasson (2015: 50-52) has pinpointed the logics that play out in relation to climate policy development. Building on these contributions, we present two ideal types of institutional logics relating to promotion of renewable energy: the market logic and the technology development logic.

First, the market logic draws on environmental economics (Boasson 2015: 51). The basic assumption is that commercial organizations possess near-perfect information and are capable of acting strategically on this information. Firms are expected to strive to maximize their profits in a medium- to long-term perspective, and governments will work to ensure that renewables investments become more profitable. Support schemes should encourage market actors to compete in 
developing the most profitable renewables projects. Thereby the 'best' projects will be developed, and the actors that manage to develop the most profitable projects will be rewarded with the greatest profits. While some economists argue that only those projects that require the lowest level of support in order to break even should be awarded renewables subsidies, others are open for support schemes that also award support to projects that are profitable at the outset (Boasson 2015).

Second, the technology development logic is based on technological rather than economic criteria (Boasson 2015: 50-52). It is assumed that emergence of increased renewables shares will hinge on technological innovation and its subsequent refinement. Commercial organizations will aim to enhance technological development, with government ensuring good and stable conditions that enable them to do so. It is the technical quality of the alternatives to conventional production that determines the support levels, so various technologies will receive differing levels of support. Further, in this logic, support schemes are designed to ensure long-term stability, so that commercial actors may invest the time and resources needed to refine the technologies in which they have greatest expertise (Sims et al. 2007: 306). In line with this approach are feed-in tariff schemes that guarantee renewable-energy producers access to the grid, a fixed level of operational support and varying levels of support for different technologies (Boasson 2015: 50-52). Here the incentives for competitive behaviour and cost minimization will be weak. Whereas the market logic favours technology-neutral support schemes, the technology-development logic favours technology-specific measures.

We seek to detect these logics in our empirical case studies, expecting variation in logics across countries. As institutional logics 'are historically contingent and evolve and change over time' (Ocasio et al. 2017: 511), we may also be able to detect significant changes in logics over time. Not least, it is reasonable to assume variation in the extent to which organizational fields will be full of conflict. As noted, fields will tend to influence policy development more when they are united. Hence, we expect the organizational field to dominate policy development more when one institutional logic is superior, than if the field is rife with conflicts.

\section{Expectations}

Understanding how the organizational fields influence developments in renewables support schemes requires assessing the structural and cultural-institutional aspects in conjunction. Table 3.2 presents segmentation and pluralism as contrasting modes. Segmentation will be in operation when structural power is largely concentrated and one professional logic dominates, implying a basically shared view on the promotion of renewable electricity. In such situations, 'some policy experts enjoy tremendous freedom of action, seldom being called upon to justify their actions' (Baumgartner and Jones [1993] 2009: 8); moreover, 'there tends to be a single understanding of the underlying policy question' (ibid.: 26). Various labels have been used to describe segmented organizational fields, like 'interest-group liberalism' (Lowi 1969), ‘segmentation' (Egeberg et al. 1978; 
Table 3.2 Four modes of the organizational field

\begin{tabular}{lll}
\hline $\begin{array}{c}\text { Structural pattern } \\
\text { Institutional pattern }\end{array}$ & Concentrated & Distributed \\
\hline One dominant logic & $\begin{array}{l}\text { SEGMENTATION } \\
\text { Drives policy development } \\
\text { TURF BATTLE }\end{array}$ & COLLABORATION \\
Several logics & PLURALISM \\
& Low importance \\
\hline
\end{tabular}

Source: Revised version of Boasson (2015: 48).

Hernes 1983: 290; Lieberson 1971) 'iron triangles' (Hernes 1983: 291), 'regulatory capture' (Carpenter and Moss 2014) and 'policy monopolies' (Baumgartner and Jones [1993] 2009: 7).

Such organizational fields have a fairly hierarchical structure, with one organization or a small group of closely aligned organizations at the top. Policy studies and sociological institutionalism literatures point in the same direction: that the importance of the organizational field to the policy outcome will be most significant in such situations. The field can be expected to influence policy more when this mechanism is in operation. Note, however, that it is primarily the dominant actors that will leave a deep footprint in such situations, while marginal actors will be less important.

In contrast, the pluralism mechanism will be in operation when structural resources are fairly evenly distributed and many different logics are in operation. Various actors will have the opportunity to influence policy development. As there will be many parallel disagreements, a broad range of minor conflicts can be expected to erupt in relation to all kinds of decision-making situations. While many pluralist approaches to public policy have held that mobilization of some groups will automatically lead to counter-mobilization, we do not expect to see this in pluralist organizational fields (Lowi 1964; Schmitter 1974). Instead, in situations where few have an intense interest in an issue, the overall influence of the organizational field on policy-making is likely to be meagre. To the extent that the field influences designs for renewables support, this will underpin the development of a set of a diverse and inconsistent mix. We may also see many shifts and turns in support mixes over time.

Not all fields can be subsumed within one of these two extreme modes. Collaboration is likely in fields where structural resources are rather evenly distributed and most participants follow the same professional logic. Actors will tend to have fairly similar viewpoints, and the level of conflict will be correspondingly low. There may be incremental change in support-scheme mixes, but as long as this mode dominates, major shifts are not expected. The turf battle mechanism is a tougher version of pluralism, where actors disagree strongly and mobilization is met with counter-mobilization. This mode of influence will emerge when structural power is fairly concentrated but varying logics are in conflict. 
Against this backdrop, we expect the organizational field to:

- dominate the development of national renewable energy policies more when characterized by centralized structural resources and one institutional logic (segmentation).

While political fields will relate to organizational fields, and often be influenced by them, they operate in a different way. Kingdon ([1984] 2011) is one of a few scholars who have argued for a clear analytical separation of organizational and political fields (which he often refers to as the 'politics' stream and the 'policy' stream). Since the two are 'largely governed by different forces, different considerations, and different styles' (Kingdon [1984] 2011: 88), we need differing analytical tools to understand how and under which conditions these two fields influence policy development. Let us now turn to the nature and dynamics of political fields.

\section{Domestic political fields}

Political fields cover the whole range of political actors: political party organizations, legislative assemblies and committees, governmental executives and the political leaders of the governmental ministries (Boasson 2015: 38-46). It is rarely meaningful to talk of one national political field. Rather, politicians in the various parliamentary committees, ministries and political parties will probably be involved in several different political fields, centred around differing policy issues. The structural and cultural-institutional character of the field in question will tend to influence the behaviour of political actors in significant ways. As in other fields, political actors take the actions and positions of others into account in deciding how to approach a given issue (DiMaggio and Powell ([1983] 1991; Kluttz and Fligstein 2016).

The comparative politics literature consists of an array of strong subliteratures - some focusing on political parties or parties on governments, others examining the roles and voting behaviour of the legislature. By contrast, the political field approach aims at assessing the special role of the political realm at large, with respect to the development of specific policy issue-areas. The voluminous political science literature shows that politics have immense importance in democratic societies, but significant disagreement persists as to how and to what extent domestic political governing plays into policy development. By combining insights from policy process theories, various comparative politics literatures and neo-institutional sociology, the political field perspective enables us to develop a more coherent understanding of the relative importance of politics for policy.

The political sociology literature of the 1950s and 1960s tended to regard political parties in European countries as representing certain 'pre-defined sectors of society', with strong ties to various societal groups (Katz and Mair 1995: 7). For instance, Stein Rokkan (1966) regarded political parties and interest groups as manifestations of underlying social cleavages. However, from the 1990s and 
onwards, it has become common to regard political parties as less dependent on such ties and increasingly reliant on the electorate channel (Katz and Mair 1995: 7). In certain issue-areas and countries, there remain deep ties between organizational fields and political parties, but by analytically distinguishing between the political and the organizational fields we can explore their relative importance, as well as their interactions and interrelationship.

The political field approach contrasts with the 'partisan influence' literature, where it is assumed that there will be clear and consistent differences in the positions of left-wing and right-wing political parties, and that differences in the party composition of governments will lead to predictable variation in policy development (see reviews in Schmidt 1996; Schmitt 2016). This literature primarily examines issues that fall in line with established societal cleavages, such as welfare or fiscal policies. Climate and energy policy tends to cross across traditional cleavages, many voters have inconsistent views, and which climate sub-issues gain salience differ across countries (Gullberg and Aardal 2019; Pidgeon 2012).

Like other fields, the political field shares structural as well as institutional characteristics. Here we explore each aspect in turn, before examining them in conjunction and developing our expectations.

\section{Structural resources}

Structurally, political fields tend to involve considerable formal authority, but little expertise. The distribution of structural resources in a given country will depend on the character of its political system, election results, alliances between political parties in the Parliament and in government and the special characteristics of the policy area in question. In the following, we discuss why concentration of structural resources within the political field contributes to reducing the policy influence of the field, whereas the distribution of resources has the opposite effect (see also Boasson 2015).

First, the distribution of political positions among political parties (the distribution of votes among parliamentary blocs and the composition of the government) delegates authority among the political parties. The relative importance of the legislative assembly, the government and the ministries will differ from country to country - depending on whether the political system is presidential, parliamentarian, federal or whatever. Moreover, the distribution of authority may vary from one issue-area to another (Baumgartner and Jones [1993] 2009: 32; Egeberg 2003; Skocpol 1985: 17).

Richard Rose $(1969,1974)$ and Richard S. Katz (1987) argue that a party will tend to have greater influence when it occupies the positions with highest authority, when key decisions are made by elected officials, clear policy stands are developed through party internal processes, and the party occupies enough positions to be able to take active part in policy development. However, as has become increasingly clear, 'these conditions are becoming marked more by their absence than by their presence in contemporary European politics' (Mair 2008: 225-226), although less so in two-party systems, as in the UK. Today, coalition governments 
of various types, as well as minority governments, have become dominant in Europe (Sagarzazu and Klüver 2017; Strøm and Müller 2000). This changes the conditions for political governing, also making it more important to capture the dynamics between the broad range of political parties, whether they are in government or not. Even though single, large parties still play important roles as developers of policy positions, actual executive decisions tend to be developed through negotiations and bargaining between differing parties and legislative committees. In contrast to Rose and Katz, we do not focus on specific parties but hold that the political field as such tends to play a more important role when formal authority is distributed among many several political parties and ministries.

Second, authority is also rooted in the executive branch of the governmental apparatus. The issue-specific formal distribution of powers among different parts of the government will affect how many ministers pay attention to an issue. While the composition of parliaments and governments changes fairly often, the distribution of authority regarding certain political arenas tends to be determined by formal rules, some of which are difficult to change, such as constitutions (Pierson 2004: 120-121). In most European democracies, a cabinet minister is the political head of a major department of state. This minister directs a team of senior civil servants and has overall responsibility for policy initiation and administration in a key area of state activity (Gallagher et al. 2011: 33-37). However, with climate and energy policy, many issues fall under the authority of several ministers, diffusing the authority over the issue.

Authority can be said to be more 'concentrated' when the results of an election create a clear majority - consisting of one party or a well-aligned coalition of parties, and when one ministry is in charge of a given issue (like climate or energy policy). In contrast, it will be 'distributed' when there is a minority government or a coalition government with differing views on the issue, and the Parliament has formal decision-making powers over the issue-area.

As for the distribution of information, the most striking thing is the lack of it. Most politicians are generalists, who rarely rely on detailed, technical types of expertise (Kingdon [1984] 2011: 37). As Martin Minogue ([1983] 1993: 16) has noted, 'information is frequently inadequate or simply not available . . . information is a resource, to be used and manipulated'. Because the parties in government have access to experts in the administrative apparatus, they tend to have more information than parties that are represented only in the legislative assembly. The governing parties can also to some extent steer which information is available to others. The better the access of oppositional politicians to alternative information sources, the less of a power-tool control over information will be for the parties in government. And if the legislators are not formally involved in the decisionmaking, they will be less informed and hence unlikely to evince interest in a given political issue.

We expect the political field to influence policy development more when structural resources (authority and information) are more broadly distributed. When structural resources are concentrated, an issue-area may escape political steering altogether. Under such conditions, the lack of political engagement will tend to 
move problem-solving downwards to the ministerial bureaucracy, or be resolved in negotiations between civil servants and corporate actors (Boasson 2015: 166). Then, the responsible minister will have few incentives for paying much attention. If the minister happens to have a special interest in the subject, that person will be in a very powerful position. Things will be radically different if authority and information are spread within the political field: the more political actors who share responsibility for an issue, the more information the politicians will have, with greater incentives for engaging and giving priority to it. In organization fields, however, the contrary will apply: the concentration of structural power will enhance the fields' influence over policy-making.

\section{High- and low-salience scripts}

The political field has other social norms, rules and understandings than those generally found in other parts of society. Because time is scarce, politicians often resort to institutionalized, cognitive scripts to make decisions about which issues to pay deeper attention to, and which to down-prioritize. In the following, we present the two contrasting cognitive scripts for low- and high-salience issues. These scripts exist independently of specific policy areas; they are coherent recipes for how to behave in relation to specific issues. Whether the high- or low-salience script is attached to an issue will have major importance for how and to what extent the political field will influence policy development within that issue-area. This holds true for schemes for renewable energy support - in focus here - but also for many other issues as well.

Inspired by March and Olsen's 'logic of appropriateness' approach (1989), Donald Searing (2012: xxv) has argued that politicians think a great deal about which behaviours are appropriate under differing circumstances. Pepper D. Culpepper (2011: 180) draws on some of the same thinking when he highlights how the political dynamics of low-salience issues differ from those of high-salience issues. 'Political salience' here concerns how important (in relation to other current issues) politicians from across the spectrum perceive an issue to be in the ongoing political debates - not how important the issue is for individual political parties. When an issue gains high salience across the political spectrum, it prompts politicians to base their behaviour on a different political cognitive script from the one they follow in relation to low-salience issues. These scripts can be seen as two different types of 'behavioural patterns or routines that legislators [and other politicians] adopt' and 'can be viewed as strategies for the employment of scarce resources' (Strøm 1997: 155)'. High- and low-salience scripts are institutionalized, behavioural patterns - but which issue-areas are understood as high salience may change over time.

Multiple, interrelated objectives motivate politicians, but they undertake more strategic thinking in relation to high- than low-salience issues. Most political parties aim to increase the number of votes, secure control over the governmental executive, and maximize their impact on public policy, but it is always challenging to assess how the three objectives influence each other (Strøm and Müller 
2000). Because there 'are plenty of competing demands on a legislator's time and attention', we need analytical tools that can help us make sense of political behaviour (Strøm 1997: 171). Distinguishing between political cognitive scripts for high- and low-salience issues can be one such tool.

Note that 'salience' is understood differently here than in election saliency research, which explores how salience of an issue varies across political parties, and focuses on how political parties selectively highlight policy issues in order to attract voter support (Budge 2015). Drawing on Culpepper (2011: 4), we focus on the perceived importance of given issues, relative to other political issues, across the political field. Whereas Culpepper argues that the salience of an issue is a result of its actual characteristics - its technical complexity in particular - we do not see the salience of an issue as something constant. Much like market actors adjust their behaviour to what other producers do, politicians position themselves in relation to other politicians (White 1981: 518). Modern political parties conduct polling to learn about public preferences, but they still have difficulty assessing the relative salience of an issue among the public (Culpepper 2011: 7). It is easier for political actors to get a sense of how salient an issue is within the political field. Table 3.3 identifies five major differences between high- and low-salience cognitive scripts.

First of all, high-salience policy areas are subject to intense political competition - low-salience issues are not. Political actors have a shared sense of the positions of other actors in the field (Kluttz and Fligstein 2016: 191), but they pay more attention to how their peers relate to high-salience than they do to low-salience issues. With high-salience issues, politicians will develop their positions in reaction to the positions of others and will generally be consistent with positions they have had before. By contrast, with low-salience issues, political actors will be much more open to inputs from organized actors. Here, individual policy-makers

Table 3.3 Two cognitive scripts in the political field

\begin{tabular}{l}
\hline \multicolumn{1}{c}{ Salience High Low } \\
$\begin{array}{l}\text { Behavioural } \\
\text { cognitive elements }\end{array}$ \\
\hline
\end{tabular}

Awareness of others'
positions

Preferences

\section{Consistency}

Reason for engaging in Policy influence. the issue

Key cause of policy change approach. over time.
High, competitive

Highly normative, simplified, general, differences amplified.

High. Incremental changes Low. Radical shifts over time.

Change in political majority or political compromises.
Symbolic attention towards voters. Bargaining chip to be used in negotiations.

Low, collaborative approach.

Unclear and ill-defined

New inputs from outside the field, or initiatives from politicians with additional time and energy. 
with special personal interest in the issue and time available to devote to the issue can have huge importance (Cohen et al. 1979: 26).

Second, in low-salience issue-areas, politicians will tend to have ill-defined preferences (Boasson 2015: 164-167; Cohen et al. 1979; Kingdon [1984] 2011). With low-salience issues, politicians will tend to adopt positions only after certain policy actions have been endorsed, as by a party in government or during parliamentary decision-making (Boasson 2015: 134-156). Hence, with low-salience issues, preferences emerge through action, while preferences tend to serve as a basis for action in high-salience issues (Cohen et al. 1979).

Further, politicians will aim to simplify the lines of conflict in high-salience issues - for instance, by portraying the disagreement as being between high and low moral attitudes, and shying away from complexities related to the design and implementation of public policies (Boasson 2015: 83-109). Politicians may also portray their positions as more unique and different from those of other political actors than is actually the case. In relation to climate issues, politicians may characterize their favoured policy option as the only possible position that will contribute to mitigation - for instance, by presenting their favoured support scheme for renewables as the only scheme that will lead to higher renewables shares, while denigrating other design options as undermining renewables and climate mitigation altogether (Boasson 2015: 109-133).

Third, because shifting stances may signal uncertainty and weak leadership, in high-salient issue-areas, political actors will seek to frame their positions as stable and consistent over time. However, they will also be eager to influence policy development (Strøm and Müller 2000: 9). It can be challenging to align these two concerns. Politicians will aim to adopt positions that are ambiguous enough to allow them to engage in compromises, but there are limits as to how far a political party can stray. Political positions on salient issues will tend to be rather sticky, but be more readily subject to change in lowsalience issue-areas (Boasson 2015: 134-156). Here, possibilities for brief positive media attention and symbolic gains can tempt politicians to jump to conclusions - and, unlike the case with high-salience areas, neither the politicians themselves nor the electorate are likely to remember their prior positions in the longer term.

Fourth, in high-salience issue-areas, political actors like to portray themselves as influential (Kingdon [1984] 2011: 39) and work systematically to influence decision-making. To this end, they will try to learn as much as they can and be active, also in relation to small and detailed matters relating to the issue (Boasson 2015: 83-108). Bargaining and negotiations will play out in multiple arenas: within political parties, within the state executive, between parliamentary coalitions, and in the media. As the political landscape in most European countries has become increasingly fragmented, cross-party arenas have become more important for deliberations than party-internal processes. Political jockeying will be less evident in relation to low-salience issues. Here, politicians will tend to be reactive, rather uncritically aligning with positions developed by others, and pay little attention to the issue in connection with major political bargains, for instance 
when political platforms and governmental platforms are negotiated (Boasson 2015: 134-156).

Since it is important to be on the winning team in high-salience issues, parties will be less willing to agree to policy sacrifices. In such situations, politicians will search for compromises that enable all parties involved in the deal to present themselves as consistent and as winners (Boasson 2015: 164-167). If they fail to identify such compromises, the political competition over the issue may move political opponents further away from each other.

Fifth, as political actors are unlikely to change their positions radically in highsalience issues, governments tend to give stable, long-term steering signals in such issue-areas. Governmental policy will tend to shift if the political majority changes. By contrast, in low-salience issues with less at stake, politicians from all parties will be more willing to make concessions to other parties, and their positions will be far less stable.

It follows from this that the political field will tend to influence policy development in high-salience issue-areas far more than in low-salience issue-areas. High-salience scripts can be coupled to only a handful of issues at a time, but while some issues are salient for only a brief period, others may remain salient for a decade or more (Boasson 2015: 164-167).

\section{Expectations}

By taking both the structural and cognitive script dimensions into account, we can better specify under what conditions the political fields will have most influence on developments in renewables support schemes. As Table 3.4 shows, legislature governing and ministerial governing are contrasting modes. Legislature governing will be at work when the structural powers (authority and information) are distributed and politicians act in line with the high-salience script. Here, almost all aspects related to the issue will be subjected to political deliberation, and politicians across the spectrum will do their utmost to win small and large decisionsituations relating to the issue. They will follow each other closely, and even very minor issues may become contended.

Table 3.4 Four modes of the political field

\begin{tabular}{lll}
\hline $\begin{array}{c}\text { Structural pattern } \\
\text { Cognitive script }\end{array}$ & Concentrated & Distributed \\
\hline High Salience & POLITICIZING & $\begin{array}{l}\text { LEGISLATURE } \\
\text { GOVERNING } \\
\text { Dives policy development } \\
\text { Low Salience }\end{array}$ \\
& MINISTERIAL & RANDOM DECISION- \\
& GOVERNING & MAKING \\
& Low policy importance & \\
\hline
\end{tabular}

Source: Revised version of Boasson (2015: 39). 
In legislature governing situations, the political field will be relatively stronger as compared with other fields. Politicians will devote considerable energy to an issue, paying close attention to how it is dealt with in other fields. The issue will be high on the agenda when party programmes are to be developed, annual meetings held, government coalitions formed and state budgets negotiated. Politicians will take the lead - not interest groups, bureaucrats or international developments. This situation can endure for many years, but not indefinitely (Boasson 2015; Downs 1972).

In ministerial governing situations, structural power is concentrated, and neither other parts of the executive government nor the Parliament have much formal authority. The low-salience script is dominant. Few other politicians are committed to the issue; it is up to the minister with the formal power to decide whether and how to intervene in a policy area. Because the issue has low salience, the minister will normally have little to gain (in terms of popularity and media attention) from becoming involved - and will therefore get involved only if that person has time to spare and personal motivation. In practice, this gives politicians only modest influence on the development of policy. Instead, the actual development of the policy in question is shaped by organizational field developments: problemsolving is moved downwards, into the ministerial bureaucracy, or among civil servants and corporate actors.

The differences between legislature and ministerial governing will rarely be clear-cut, and more a matter of degree. Moreover, there may be intermediate situations. Politicizing is when an issue has become highly salient, but structural power concerning that issue is still concentrated. Despite their lack of formal powers, wider parts of the political field will engage in the issue, and political parties will compete over it. Some issues can be solved through politicizing, and the issue will then shift back into the ministerial governing positions - but the conflict may also escalate and shift towards the legislature governing situation. In political systems with strong parliaments and/or coalition governments, this situation will probably lead to the Parliament gaining more formal power regarding the issue - with a shift towards legislature governing. Whether this will happen will depend on the tactics of the sitting government as well as the opposition - and elections may have a significant role here.

Random steering will be seen in low-salience issues when many ministries and/or legislative committees share authority over an issue-area, or when formal decision-making authority over an issue is not clearly defined (Baumgartner and Jones [1993] 2009: 32). As regards other issues, there will be little political competition, and few actors will have time and energy to focus on such matters. Here the importance of the political field will depend primarily on the strength of the organizational field.

Against this backdrop, we expect the political field to:

- dominate the development of national renewable-energy policies more when characterized by distributed structural resources and high salience (legislature governing). 
However, the political field will develop and change through a dynamic interrelationship with the domestic organizational field and the European environment. We end this chapter with a brief discussion of the dynamic interrelationships between the multiple fields presented here.

\section{Multi-field dynamics and interrelationships}

Understanding how and why renewables support mixes evolve and change over time calls for examination of the role and importance of the differing fields, but also of how they interact and relate to each other over time. In the following, we summarize the field-specific expectations before we specify some crucial interfield dynamics.

Figure 3.1 offers a simplified picture of the relationship between the many fields at one specific moment in time. Many countries may be involved, but the figure presents only three examples. The relationship between the two domestic fields may be weak, with only a few contact points - or they may be closely related, with strong ties or overlaps. Moreover, the domestic fields may be more or less integrated into the European environment. For instance, there may be strong bilateral links between domestic organization fields and European fields. For instance, national energy agencies may collaborate extensively with sister agencies in other European countries, and the dominant domestic electricity utilities may also have

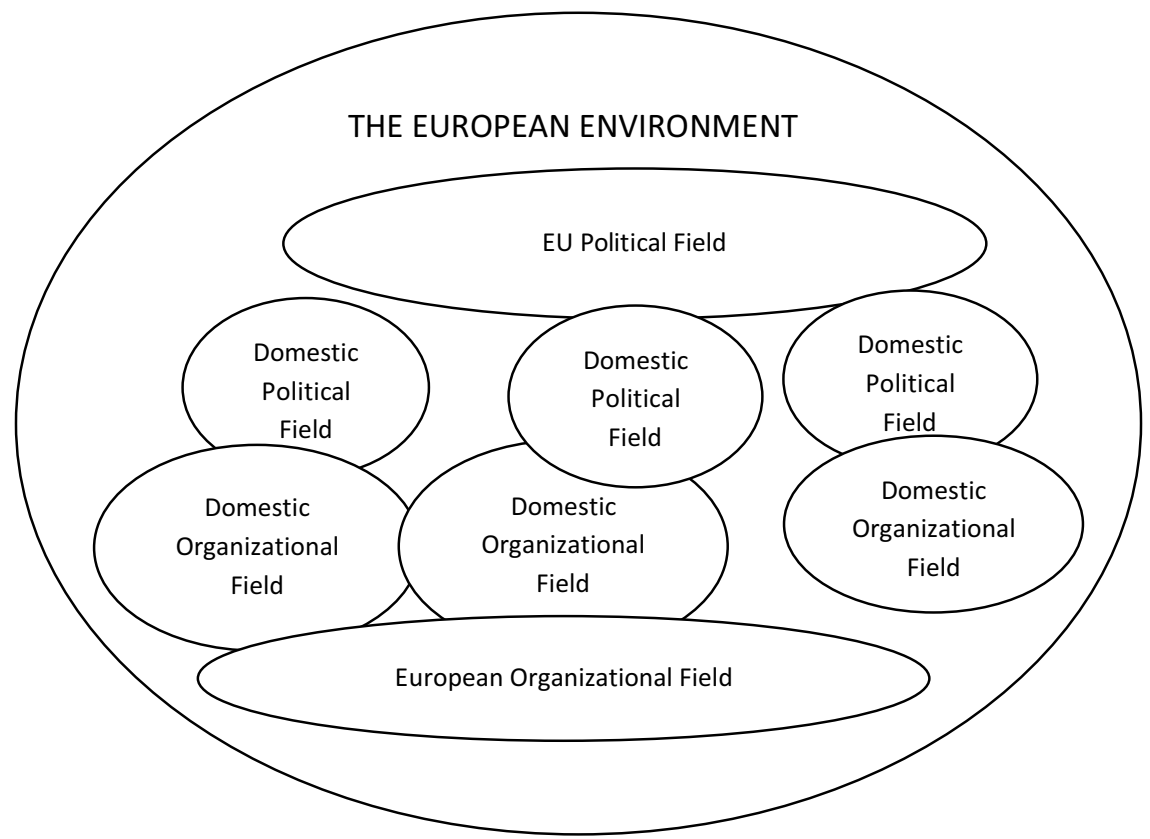

Figure 3.1 Multiple fields involved in European renewables support-scheme developments 
a strong presence in many other EU and EEA countries. Under such conditions there will be significant overlaps between the domestic and European organizational fields of electricity. In contrast, regulators and agencies that rarely engage in European networks and corporations that are active in only one country are not well integrated in the European organizational field.

Secondly, while some domestic political fields are strongly linked to the European political field, others have weaker links. For instance, as Norway is not an EU member and thus does not take part in political deliberations in Brussels, it is likely to have weaker links to the European political field than full member states. In other counties, the dominant domestic political parties may have strong representation in the European Parliament and on the Commission.

Figure 3.1 does not show how fields at all levels may evolve and change characteristics and interrelationships over time. In examining the multi-field dynamics that have shaped the development of renewables support, we will aim to detect patterns as to multi-field correlations, causation and interrelationships as well as multi-field effects on policy developments.

Concerning correlations, we will search for answers to the following questions. Do certain organizational and political field-level modes tend to occur in tandem? For instance, does the 'ministerial governing' mode tend to occur when the domestic organizational field has certain characteristics? Further, is there any pattern of certain domestic field characteristics that correlate with given European environment characteristics? For instance, does the 'EU governing' mode in the European environment occur at the same time as the domestic fields, assuming certain characteristics? As the interactions between the domestic and the EUlevel developments play out over time and at any point in time, the domestic and the European levels may interact (Saurugger 2014a, 2014b). In this volume, we understand Europeanization as a process and not as an exogenous influence on domestic developments. However, organizational and political fields in differing countries will interact with the EU in varying ways, and there is still much to learn about the possible relationships and interdependencies between domestic developments and EU-level developments, and how these patterns may differ across countries and over time.

If interesting correlations emerge, the next step will be to consider whether there are causal interrelationships between fields. In order to detect causation and interdependencies, we will pay particular attention to the timing related to shifts in modes across fields. If one field tends to change its mode after another field has changed its mode, that may indicate a causal relationship between the two. Alternatively, simultaneous changes in several fields may indicate interdependencies.

We also ask: Are changes in domestic organizational and political fields causally related? If so, does one field cause changes in another field-are they mutually interdependent? For instance, 'legislature governing' may spur uncertainty and conflicts at the organizational level, or the reverse: conflicts at the organizational field level may cause an issue to shift from 'ministerial governing' to 'legislature governing' within the political field. Further, because organizational fields are particularly dominant when segmented, this may spur developments 
towards ministerial governing. But the reverse causal relationship is also possible: that political fields in ministerial governing mode allow the organizational field to become more segmented. By paying attention to how the two fields change over time, we may uncover certain patterns with respect to interrelations and interdependence.

Further, we will pay attention to causal relationships between the European environment and the domestic fields: Are changes in domestic- and Europeanlevel fields causally related? If so, does one level cause changes at other levels, or are they mutually interdependent? In order to understand the role that the six countries studied here have had in relation to the wider Europeanization process, at least two differing features may be important. First, differing domestic fields may have played differing roles in horizontal as well as vertical Europeanization processes. Some domestic fields may be primarily senders of support-mix ideas; others may be primarily receivers. The latter group may be inspired by developments in other European countries as well as by EU-level actors and developments. Whether a domestic field mainly provides or receives support-scheme ideas may also change over time.

Moreover, countries may differ with respect to their dependence on EU-level developments. In some countries, prominent domestic actors, from the political or organizational fields, may assume pro-active roles towards the EU and call for stronger or different EU regulations. In other countries, actors may be fairly content with the existing EU rules and develop domestic policies less affected by discussions at the EU level. In countries where the political majority or strong organizational field actors find that EU steering is at odds with their favoured renewables support mixes, the EU rules in that issue-area will probably become controversial. Under such circumstances, the country will become dependent on future EU developments. In contrast, countries where the political majority and/ or strong organizational field actors regard EU rules as unproblematic may not become very involved in getting the EU steering to change, and it will not be contested nationally.

Our main reason for exploring the interrelationship between multi-field developments is to see how these change processes affect changes in support-scheme mixes over time. We want to find out whether certain multi-field configurations create specific, patterned constraints and enablers for certain developments in renewables support mixes.

\section{Summary}

This chapter has presented expectations related to the importance of the European environment, the organizational fields and the political field for renewable electricity support mix development. We expect the dominance of the three differing social spheres to be greater when they have certain structural and culturalinstitutional characteristics. More specifically:

- The European environment will dominate the development of national renewable energy policies more when the vertical Europeanization is strong 
and the horizontal Europeanization is coherent, implying that one specific support-scheme mix gains superiority (EU governing).

- The organizational field will dominate the development of national renewable energy policies more when the field is characterized by centralized structural resources and one institutional logic (segmentation).

- The political field will dominate the development of national renewable energy policies more when the field is characterized by distributed structural resources and high salience (legislature governing).

These expectations focus on the effect of each of the separate social spheres, but without taking the interrelationship between fields into account. However, the two domestic fields and the many European fields that shape a policy issue like renewables support may be interrelated, in differing ways across time and countries. This means that the social characteristics of the various fields may to a certain extent be shaped by developments in other fields. In systematically comparing our six case studies in Chapter 11, we ask:

- Do certain organizational and political field-level modes occur in tandem?

- Are changes in domestic organizational and political fields causally related? If so, does one field cause changes in another field - or are they mutually interdependent?

- Are changes in domestic- and European-level fields causally related? If so, does one level cause changes at other levels - or are they mutually interdependent?

\section{References}

Baumgartner, F.R. \& B.D. Jones ([1993] 2009) Agendas and Instability in American Politics, 2nd ed. Chicago, IL: University of Chicago Press.

Boasson, E.L. (2015.) National Climate Policy: A Multi-field Approach. London: Routledge.

Boasson, E.L. (2021) 'Europeanization of renewables support', pp. 58-72 in E.L. Boasson, M.D. Leiren \& J. Wettestad (eds) (this book), Comparing Renewables Policy: The Role of Political, Organizational and European Fields. London: Routledge.

Boasson, E.L., M.D. Leiren \& J. Wettestad (2021) 'Comparative assessments and conclusions', pp. 219-239 in E.L. Boasson, M.D. Leiren \& J. Wettestad (eds) (this book), Comparing Renewables Policy: The Role of Political, Organizational and European Fields. London: Routledge.

Börzel, T.A. (1998) 'Organizing Babylon - on the different conceptions of policy networks', Public Administration 76: 253-273.

Börzel, T.A. \& T. Risse (2012) 'From Europeanisation to diffusion: Introduction', West European Politics 35(1): 1-19.

Budge, I. (2015) 'Issue emphases, saliency theory and issue ownership: A historical and conceptual analysis', West European Politics 38(4): 761-777.

Bulmer, S.J. \& C.M. Radaelli (2004) 'The Europeanisation of national policy?' in Queen's Papers on Europeanisation. Belfast: Queens University Belfast.

Carpenter, D. \& D.A. Moss (2014) Preventing Regulatory Capture. Cambridge: Cambridge University Press. 
Cohen, M.D., J.G. March \& J.P. Olsen (1979) 'People, problems, solutions and the ambiguity of relevance', in J.G. March \& J.P. Olsen (eds), Ambiguity and Choice in Organizations. Oslo: Scandinavian University Press.

Cowles, M.G. \& T. Risse (2001) 'Transforming Europe', in M.G. Cowles, J. Caporaso \& T. Risse (eds), Transforming Europe: Europeanization and Domestic Change. Ithaca, NY: Cornell University Press.

Culpepper, P. (2011) Quiet Politics and Business Power: Corporate Control in Europe and Japan. Cambridge: Cambridge University Press.

DiMaggio, P.J. \& W.W. Powell (1983) 'The iron cage revisited', American Sociological Review 48(2): 147-160.

DiMaggio, P.J. \& W.W. Powell (1991) The Neo-institutionalism in Organizational Analysis. Chicago, IL: University of Chicago Press.

Dobbin, F., B. Simmons \& G. Garrett (2007) 'The global diffusion of public policies: Social construction, coercion, competition, or learning?' Annual Review of Sociology 33: 449-472.

Downs, A. (1972) 'Up and down with ecology - the issue-attention cycle', Public Interest 28: $38-50$.

Egeberg, M. (2003) 'How bureaucratic structure matters: An organizational perspective', pp. 116-126 in B.G. Peters \& J. Pierre (eds), Handbook of Public Administration. Thousand Oaks, CA: Sage.

Egeberg, M., J.P. Olsen \& H. Sæthren (1978) ‘Organisasjonssamfunnet og den segmenterte stat', in J.P. Olsen (ed), Politisk Organisering. Bergen: Universitetsforlaget.

Eising, R. (2004) 'Multilevel governance and business interests in the European Union', Governance 17(2): 211-245.

Finnemore, M. \& K. Sikkink (1998) 'International norm dynamics and political change', International Organization, 52: 887-917.

Fligstein, N. \& D. McAdam (2012) A Theory of Fields. Oxford: Oxford University Press.

Gallagher, M., M. Laver \& P. Mair (2011) Representative Government in Modern Europe, 5th ed. Maidenhead: McGraw-Hill Higher Education.

Greenwood, R. \& R. Suddaby (2006) 'Institutional entrepreneurship in mature fields: The big five accounting firms', Academy of Management Journal 49(1): 27-48.

Gullberg, A.T. \& B. Aardal (2019) 'Is climate change mitigation compatible with environmental protection? Exploring voter attitudes as expressed through "old" and "new" politics in Norway', Environmental Policy and Governance 29: 67-80.

Hernes, G. (1983) Det Moderne Norge: Makt Og Styring. Oslo: Gyldendal Norsk Forlag.

Hooghe, L. (2001) The European Commission and the Integration of Europe: Images of Europe. Cambridge: Cambridge University Press.

Hooghe, L. \& G. Marks (2001) Multilevel Governance and European Integration. Lanham, MD: Rowman \& Littlefield.

Jörgens, H. \& I. Solorio (2017) 'The EU and the promotion of renewable energy: An analytical framework', pp. 3-22 in I. Solorio \& H. Jörgens (eds), A Guide to EU Renewable Energy Policy: Comparing Europeanization and Domestic Policy Change in EU Member States. Cheltenham: Edward Elgar.

Katz, R.S. (1987) 'Party government and its alternatives', in R.S. Katz (ed), Party Governments: European and American Experiences. Florence: EUI/ Berlin: de Gruyter: 1-26.

Katz, R.S. \& P. Mair (1995) 'Changing models of party organization and party democracy', Party Politics 1: 5-28.

Kingdon, J.W. ([1984] 2011) Agendas, Alternatives, and Public Policies. Boston, MA: Little, Brown. 
Kluttz, D.N. \& N. Fligstein (2016) 'Varieties of sociological field theory', pp. 185-204 in S. Abrutyn (ed), Handbook of Contemporary Sociological Theory. Cham, Switzerland: Springer International.

Kohler-Koch, B. (1999) 'The evolution and transformation of European governance', pp. 14-35 in B. Kohler-Koch \& R. Eising (eds), The Transformation of Governance in the European Union. London: Routledge.

Lieberson, S. (1971) 'An empirical study of military-industrial linkages', American Journal of Sociology 76(4): 562-584.

Lounsbury, M. (2007) 'A tale of two cities', Academy of Management Journal 50(2): 289-307.

Lowi, T.J. (1964) 'Review: American business, public policy, case studies and political theory', World Politics 16(4): 677-715.

Lowi, T.J. (1969) The End of Liberalism: Ideology, Policy and the Crisis of Public Authority. New York: W.W. Norton.

Mair, P. (2008) 'The challenge to party government', West European Politics 31(1/2): 211-234.

March, J.G. \& J.P. Olsen (1989) Rediscovering Institutions. New York: Free Press.

Mastenbroek, E. (2005) 'EU compliance: Still a black hole?' Journal of European Public Policy 12(6): 1103-1120.

Mazey, S. \& J. Richardson (2006) 'Interest groups and EU policy-making: Organisational logic and venue shopping', pp. 247-268 in J. Richardson (ed), European Union: Power and Policy-making. London: Routledge.

Meyer, J.W. (2000) 'Globalization: Sources and effects on national states and societies', International Sociology 15(2): 233-248.

Meyer, J.W., J. Boli, G.M. Thomas \& F.O. Ramirez (1997) 'World society and the nationstate', American Journal of Sociology 103(1): 144-181.

Meyer, J.W. \& B. Rowan (1977) 'Institutionalized organizations: Formal structure as myth and ceremony', American Journal of Sociology 83: 340-363.

Minogue, M. ([1983] 1993) 'Theory and practice in public policy and administration', pp. 10-29 in M. Hill (ed), The Policy Process: A Reader. Hemel Hempstead: Prentice Hall/Harvester Wheatsheaf. [First published in Policy and Politics 1983].

Moravcsik, A. (1999) 'A new statecraft? Supranational entrepreneurs and international cooperation', International Organization 53(2): 267-306.

Newman, A.L. (2008) 'Building transnational civil liberties: Transgovernmental entrepreneurs', International Organization 62 (Winter): 103-130.

Ocasio, W., P. Thornton \& M. Lounsbury (2017) 'Advances to the institutional logics perspective', pp. 535-558 in R. Greenwood, C. Oliver, T.B. Lawrence \& R.E. Meyer (eds), The Sage Handbook of Organizational Institutionalism. Thousand Oaks, CA: Sage.

Olsen, J.P. (1983) Organized Democracy: Political Institutions in a Welfare State: The Case of Norway. Oslo: Universitetsforlaget.

Pidgeon, N. (2012) 'Public understanding of, and attitudes to, climate change: UK and international perspectives and policy', Climate Policy 12(1): 85-106.

Pierson, P. (2004) Politics in Time: History, Institutions and Social Analysis. Princeton, NJ: Princeton University Press.

Radaelli, C. (2003) 'The Europeanization of public policy', pp. 27-56 in K. Featherstone \& C. Radaelli (eds), The Politics of Europeanization. Oxford: Oxford University Press.

Reay, R. \& C.R. Hinings (2009) 'Managing the rivalry of competing institutional logics', Organization Studies 30(6): 629-652. 
Rhodes, R.A.W. \& D. March (1992) 'New directions in the study of policy networks', European Journal of Political Research 21: 181-205.

Risse, T., M.G. Cowles \& J. Caparaso (2001) 'Europeanization and Domestic Change', pp. 1-20 in M.G. Cowles, J. Caporaso \& T. Risse (eds), Transforming Europe: Europeanization and Domestic Change. Ithaca, NY: Cornell University Press.

Rokkan, S. (1966) 'Norway: Numerical democracy and corporative pluralism', in R.A. Dahl (ed), Political Oppositions in Western Democracies. New Haven, CT: Yale University Press.

Rose, R. (1969) 'The variability of party government: A theoretical and empirical critique', Political Studies 17(4): 413-145.

Rose, R. (1974) The Problem of Party Government. London: Macmillan.

Sagarzazu, I. \& H. Klüver (2017) 'Coalition governments and party competition: Political communication strategies of coalition parties', Political Science Research and Methods 5(2): 333-349.

Saurugger, S. (2014a) Theoretical Approaches to European Integration. Basingstoke: Palgrave Macmillan.

Saurugger, S. (2014b) 'Europeanisation in times of crisis', Political Studies Review 12(2): 181-192.

Schattschneider, E.E. (1960) The Semisovereign People. New York: Holt, Rinehart \& Winston.

Schmidt, M.G. (1996) 'When parties matter: A review of the possibilities and limits of partisan influence on public policy', European Journal of Political Research 30: 155-183.

Schmidt, V. (2018) "Rethinking EU Governance: From "Old" to "New" Approaches to Who Steers Integration', Journal of Common Market Studies 56(7): 1544-1561.

Schmitt, C. (2016) 'Panel data analysis and partisan variables: How periodization does influence partisan effects', Journal of European Public Policy 23(10): 1442-1459.

Schmitter, P.C. (1974) 'Still the century of corporatism?' Review of Politics 36(1): 85-131.

Schneiberg, M. \& E.S. Clemens (2006) 'The typical tools for the job: Research strategies in institutional analysis', Sociological Theory 24(3): 195-221.

Scott, W.R. ([2001] 2014) Institutions and Organizations: Ideas, Interests and Identities, 4th ed. Los Angeles, CA: Sage.

Scott, W.R., M. Ruef, P.J. Mendel \& C.A. Caronna (2000) Institutional Change and Healthcare Organizations. Chicago, IL: University of Chicago Press.

Searing, D. (2012) 'Preface', pp. xxi-xxvii in M. Blomgren \& O. Rozenberg (eds), Parliamentary Roles in Modern Legislatures. London: Routledge.

Selznick, P. (1957) Leadership in Administration. New York: Harper \& Row.

Sims, R.E.H., R.N. Schock, A. Adegbululgbe, J. Fenhann, I. Konstantinaviciute et al. (2007) 'Energy supply', Chapter 4 in B. Metz, O.R. Davidson, P.R. Bosch, R. Dave \& L.A. Meyer (eds), Climate Change 2007: Mitigation. Cambridge: Cambridge University Press.

Skocpol, T. (1985) 'Bringing the state back in: Strategies of analysis in current research', pp. 3-28 in P.B Evans, D. Rueschemeyer \& T. Skocpol (eds), Bringing the State Back in. Cambridge: Cambridge University Press.

Strøm, K. (1997) 'Rules, reasons and routines: Legislative roles in parliamentary democracies', The Journal of Legislative Studies 3(1): 155-174.

Strøm, K. \& W. Müller (2000) 'Political parties and hard choices', pp. 1-35 in K. Strøm \& W. Müller (eds), Policy, Office or Votes: How Political Parties in Western Europe Make Hard Decisions. Cambridge: Cambridge University Press. 
Thomann, E. (2015) 'Customizing Europe: Transposition as bottom-up implementation', Journal of European Public Policy 22(10): 1368-1387.

Thornton, P.H. (2004) Markets from Culture. Institutional Logics and Organizational Decisions in Higher Education Publishing. Stanford, CA: Stanford University Press.

Thornton, P.H. \& W. Ocasio (1999) 'Institutional logics and the historical contingency of power in organizations', American Journal of Sociology 105(3): 801-843.

Thornton, P.H. \& W. Ocasio (2008) 'Institutional logics', pp. 99-129 in R. Greenwood, C. Oliver, K. Sahlin \& R. Suddaby (eds), The Sage Handbook of Organizational Institutionalism. Thousand Oaks, CA: Sage.

Thornton, P.H., W. Ocasi \& M. Lounsbury (2012) The Institutional Logics Perspective: A New Approach to Culture, Structure and Process. Oxford: Oxford University Press.

Trondal, J. (ed) (2017) The Rise of Common Political Order: Institutions, Public Administration and Transnational Space. Cheltenham: Edward Elgar.

White, H.C. (1981) 'Where do markets come from?' American Journal of Sociology 87(3): 517-547.

Wooten, M. \& A.J. Hoffman (2017) 'Organizational fields: Past, present and future', pp. 55-74 in R. Greenwood, C. Oliver, T.B. Lawrence \& R.E. Meyer (eds), The Sage Handbook of Organizational Institutionalism, 2nd ed. Thousand Oaks, CA: Sage. 